\title{
Single step recombinant human follicle stimulating hormone purification by peptide affinity chromatography
}

\author{
Juan M. Gurevich Messina ${ }^{1}$, Silvana L. Giudicessi ${ }^{1}$, Mara C. Martinez-Ceron${ }^{1}$, Nicols Urtasun ${ }^{1}$, Guillermina Forno ${ }^{2}$, \\ Laura Mauro ${ }^{2}$, Osvaldo Cascone ${ }^{1}$, Silvia A. Camperi ${ }^{1}$ \\ ${ }^{1}$ Universidad de Buenos Aires. FFyB. Cát. Biotecnologia. CONICET-UBA, Inst. NANOBIOTEC. Junín 956, 1113, Bs As., Argentina \\ R\&D Zelltek S.A., UNL, FBCB, Ciudad Universitaria, Paraje el Pozo, CC 242, Santa Fe, Argentina
}

https://doi.org/10.17952/35EPS.2018.127

\section{Introduction}

Human Follicle Stimulating Hormone (hFSH) is clinically used for ovulation in women and spermatogenesis induction in men, in assisted reproduction technologies (1). As FSH-based biopharmaceuticals are parenterally administered, their purity must be high. Current methods for hFSH purification include several chromatographic steps to reach the required purity. However, these involve a decrease in the hFSH total yield and rises the cost of the process. Affinity chromatography (AC) consists in the specific adsorption of target biomolecules onto ligands immobilized on chromatographic supports. Short peptides have been described as useful ligands for AC because of their low cost, simple chemical synthesis and high stability compared to protein-based ligands (2). The aim of this work was to design an affinity chromatography matrix with an immobilized synthetic peptide for rhFSH purification.

\section{Methods}

In a previous work, Sohn et al. (3) examined the hFSH receptor interaction with the hormone, testing each amino acid of the exoloop 3 by Ala substitution. Taking into account those works, the mutant with greater affinity: (580)KVPLITVSKAK(590) was selected to design a synthetic ligand for affinity chromatography (AC): Ac-KVPLTVSKAKV AC- $\mathrm{NH}_{2}$. The peptide was synthesized as amide and was acetylated. The peptide was acetylated to increase its stability against possible attack by proteases present in the crude FSH sample. A Cys was incorporated at the C-termini to facilitate its subsequent immobilization to the chromatographic activated SulfoLink agarose resin. A sample of crude rhFSH was loaded to the peptide affinity column using as adsorption and elution buffers: $20 \mathrm{mM}$ sodium phosphate, $0.5 \mathrm{mM} \mathrm{Met}$, $\mathrm{pH} 5.6$ and 7.2 respectively.

\section{Results and Discussion}

The affinity chromatography support with the peptide ligand immobilized was evaluated by loading crude samples composed of host cell proteins from the Chinese hamster ovary (CHO) cell and rhFSH (Fig. 1). A nonreducing SDS-PAGE was done to check rhFSH purification(Fig. 2). The purity obtained after AC purification was $94 \%$ and the yield was $41 \%$ (Table 1). The highly glycosylated isoforms, which have the highest in vivo potency, were recovered. The identity of the protein band obtained in the SDS-PAGE was checked by peptide mapping analysis using LC-MS/MS. The peptide affinity column was overloaded, and the dynamic capacity obtained was $54.6 \mathrm{mg} \mathrm{rhFSH} / \mathrm{mL}$ chromatographic resin. 


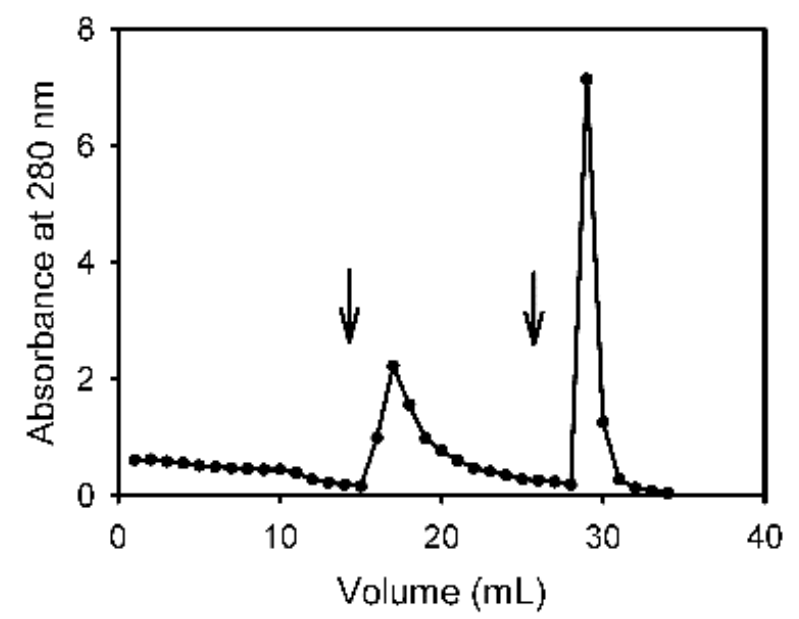

Figure 1: Chromatography of crude samples with host cell proteins and rhFSH using the affinity matrix with the peptide Ac-KVPLTVSKAKVAC-NH $\mathrm{H}_{2}$ immobilized. The mobile phases were: a) adsorption buffer (20 mM sodium phosphate, $0.5 \mathrm{mM} \mathrm{Met,} \mathrm{pH} \mathrm{5.6);} \mathrm{b)} \mathrm{elution} \mathrm{buffer} \mathrm{(20} \mathrm{mM} \mathrm{sodium} \mathrm{phosphate,} 0.5 \mathrm{mM} \mathrm{Met,pH} \mathrm{7.2)} \mathrm{and}$ c) regeneration buffer $(20 \mathrm{mM}$ sodium phosphate, $\mathrm{pH} 7.2,2 \mathrm{M} \mathrm{NaCl})$. The arrows indicate the buffer change. The rhFSH eluted when the elution buffer was added.

Table 1: Purification chart of a crude sample of rhFSH with the host cell proteins after chromatography with the affinity matrix with Ac-KVPLTVSKAKVAC-NH $\mathrm{H}_{2}$ immobilized.

\begin{tabular}{lllllll}
\hline Sample & $\begin{array}{l}\text { Volume } \\
(\mathrm{mL})\end{array}$ & $\begin{array}{l}\text { Conc. rhFSH } \\
(\mathrm{mg} / \mathrm{mL})\end{array}$ & $\begin{array}{l}\text { Total protein } \\
(\mathrm{mg} / \mathrm{mL})\end{array}$ & $\begin{array}{l}\text { Purity \% } \\
(\mathrm{mg} / \mathrm{mg})\end{array}$ & $\begin{array}{l}\text { Fold } \\
\text { purification }\end{array}$ & $\begin{array}{l}\text { Yield } \\
(\%)\end{array}$ \\
\hline $\begin{array}{l}\text { Crude } \\
\text { sample }\end{array}$ & 17 & 0.727 & 1.203 & 60.4 & - & - \\
Eluate & 6 & 0.845 & 0.899 & 94.0 & 1.56 & 41 \\
\hline
\end{tabular}

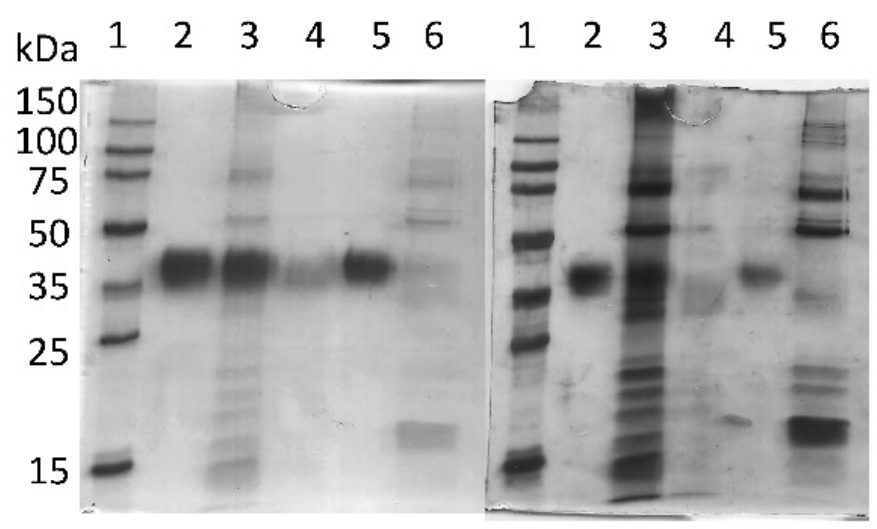

Figure 2: Non-reducing SDS-PAGE of the chromatographic step to check rhFSH purification. Left: Coomassie Blue staining. Right: Silver staining. Lane 1) protein molecular weight marker; Lane 2) standard of pure rhFSH; Lane 3) crude sample of rhFSH; Lane 4) washing fractions; Lane 5) elution fraction; Lane 6) regeneration fraction.

After its purification, rhFSH quality was analyzed. The percentage of oxidized rhFSH was $3.4 \%$ and the percentage of free subunits was $1.2 \%$, both within the range established by the European Pharmacopeia as also were the sialic acid content and the isoforms profile. 


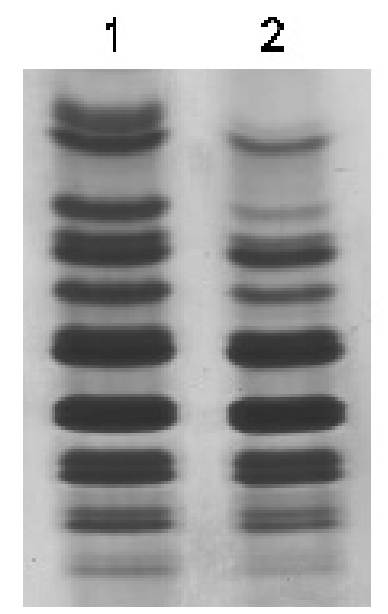

Figure 3: IEF gel for isoforms profile. 1) rhFSH standard; 2) sample of rhFSH purified by AC

\section{Conclusions}

A new affinity chromatography matrix with an immobilized peptide was synthesized for rhFSH purification. The method here designed allows obtaining a high quality rhFSH using a low-cost affinity matrix based on a short peptide ligand. The isoforms with high content of sialic acid were recovered by this new chromatographicstep. These isoforms have higher plasma half-life and hence higher in-vivo potency. Furthermore, the physicochemical analysis complied with the limits established in European Pharmacopoeia for follitropin containing samples. These results evidence that affinity chromatography with the ligand peptide A c-KVPLTVSKAKVAC-NH $\mathrm{H}_{2}$ is a promising strategy for rhFSH purification from $\mathrm{CHO}$ crude extracts. The invention has been presented to the National Institute of Industrial Property, Argentine (Act INPI: No. 2017010281, 2017).

\section{Acknowledgements}

S.L.G, M.C.M.C, N.U., O.C. and S.A.C. are researchers of the Consejo Nacional de Investigaciones Científicasy Técnicas ( CONICET). This work was partially supported by the Universidad de Buenos Aires (20020170100030B A), the Ministerio de Ciencia, Tecnologa e Innovación Productiva de la República Argentina (PICT-2014-1508) and the Consejo Nacional de Investigaciones Científicas y Técnicas de la República Argentina (PIP 11220130100119CO).

\section{References}

1. Smitz J, Wolfenson C, Chappel S, Ruman J. Reprod. Sci. 2016; 23: 706-716. DOI: 10.1177/1933719115607992

2. Camperi SA, Martínez-Ceron MC, Giudicessi SL, Marani MM, Albericio F, Cascone O. En: Methods Mol Biol. 2014;1129:277-302. DOI: 10.1007/978-1-62703-977-2_22.

3. Sohn J, Ryu K, Sievert G, Jeoung M, Ji I, Ji TH. Follicle-stimulating hormoneinteracts with exoloop 3 of the receptor. J Biol Chem. 2002 Dec 20;277(51):50165-75. DOI 10.1074/jbc.M207646200. 